Chapman University

Chapman University Digital Commons

Art Faculty Articles and Research

Art

2015

\title{
Historicity, Achronicity, and the Materiality of Cultures in Colonial Brazil
}

Amy J. Buono

ChapmanUniversity, buono@chapman.edu

Follow this and additional works at: https://digitalcommons.chapman.edu/art_articles

Part of the Art and Design Commons, Contemporary Art Commons, Ethnic Studies Commons, Latin American History Commons, Latin American Languages and Societies Commons, Latin American Studies Commons, Latina/o Studies Commons, Other History of Art, Architecture, and Archaeology Commons, Other International and Area Studies Commons, and the Theory and Criticism Commons

\section{Recommended Citation}

Buono, Amy. "Historicity, Achronicity, and the Materiality of Cultures in Colonial Brazil." Getty Research Journal 7 (2015): 19-34. https://doi.org/10.1086/680732

This Article is brought to you for free and open access by the Art at Chapman University Digital Commons. It has been accepted for inclusion in Art Faculty Articles and Research by an authorized administrator of Chapman University Digital Commons. For more information, please contact laughtin@chapman.edu. 


\section{Historicity, Achronicity, and the Materiality of Cultures in Colonial Brazil}

Comments

This article was originally published in Getty Research Journal, volume 7, in 2015. DOI: 10.1086/680732

\section{Copyright}

University of Chicago Press 


\section{Historicity, Achronicity, and the Materiality of Cultures in Colonial Brazil}

Amy J. Buono

\section{Art Historical Frames}

Disciplinarily, art historians gravitate toward a normative range of artifactsarchitecture, sculpture, painting, and decorative arts - that fall within the confines of traditional "fine arts" categories and for which there are established analytical methodologies. Similarly, the historical and institutional development of the discipline has encouraged scholars to focus upon schools of art defined by political and linguistic territorial boundaries and by (equally normative) stylistic periods. These disciplinary tendencies frequently inflect histories of colonial art, resulting in the valorizing of artworks that fit comfortably within these cultural and temporal precincts and the marginalizing of other sorts of artifacts that do not.

Art of colonial Brazil, for example, is most often represented by the architecture and sculpture of Antônio Francisco Lisboa (Aleijadinho, 1730/38-1814), such as this facade from the Church of Saint Francis of Assisi in Ouro Preto in the state of Minas Gerais (fig. 1). ${ }^{1}$ Aleijadinho's church facades and sculptures in wood and soapstone are routinely illustrated in art historical surveys of Brazilian colonial art. They serve as wellknown examples of the splendors of the colonial mining towns, in no small part thanks to Brazilian modernists' attention to Baroque art and their valorization of an Afro-Brazilian cultural heritage. ${ }^{2}$ However, the complex interactions among the many participants in colonial Brazil's interculture, which included diverse indigenous peoples, many European and African cultures, and numerous artistic and religious cultures, generated a vastly more varied corpus of artworks than that exemplified by the Baroque sculpture and churches of Minas Gerais. What would it mean to construct a history of colonial Brazilian art that takes seriously the full range of material culture from the entire colonial period?

In the Brazilian context, one encounters a body of art that is disciplinarily uncomfortable, that is nonnormative in terms of materials, forms, and functions. These artworks cannot easily be interpreted within standard formal, stylistic, or social terms. As colonial objects they are not inextricably transcultural nor strictly indigenous, European, African, or Asian, and they incorporate elements of multiple belief systems. Furthermore, the historian must remember that many of these objects remain potent for living Brazilian cultures. In this way, they belong to what Dipesh Chakrabarty calls the "ontological now," which stresses the continuous relationship between past and present 


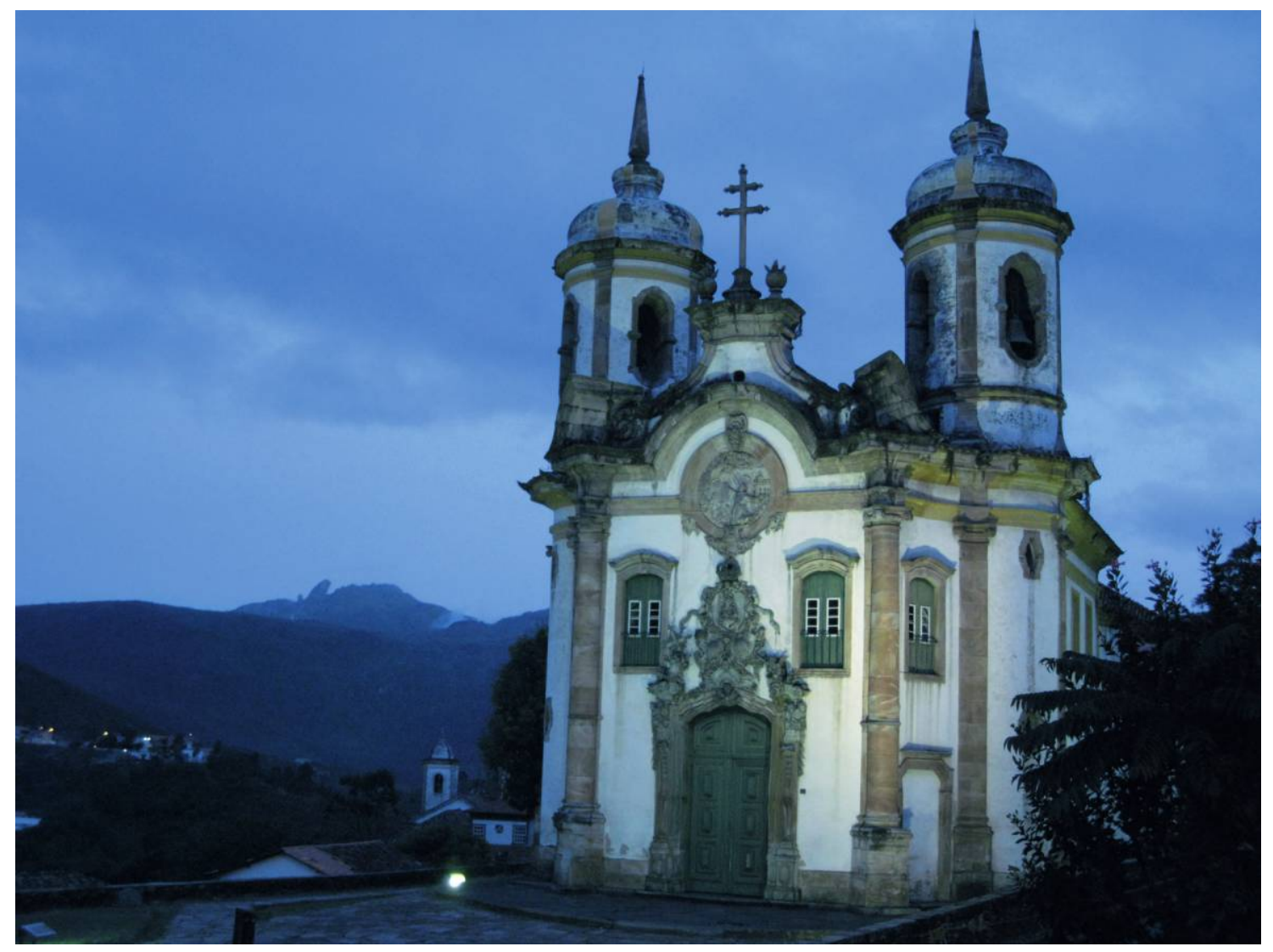

Fig. 1. O Aleijadinho [Antônio Francisco Lisboa] (Brazilian, 1730/38-1814). Facade of the Chapel of the Third Order of Saint Francis of Assisi, Ouro Preto, Minas Gerais, Brazil, built ca. 1766. Photo: With kind permission of Kirk L. Peterson, MD

practices - between modernity and everything before. ${ }^{3}$ By using the term achronicity in the title of this essay, I refer to the fact that such living objects cannot easily be contained within a traditional historical chronology. If approached as potently spiritual, many Brazilian artworks must be seen as ontologically self-sufficient and not only as historically contingent artifacts. ${ }^{4}$

In this essay, I use three nontraditional forms from the visual culture of colonial Brazil-Tupinambá featherwork, Portuguese Atlantic mandinga pouches, and azulejos (tilework) - in order to meditate upon materiality and temporality as methodological problems with which our discipline should engage. Each of these art forms has historical trajectories that span cultures, continents, and centuries, a circumstance that raises questions as to how such diverse and stubbornly nonhistoricizable genres can be melded into a coherent historical narrative of the visual and material cultures specific to "Brazil," especially when two of them - the mandinga bags and azulejos - are not intrinsically Brazilian.

This issue raises what is still an unresolved question for art history: what do we understand "Brazil" to be, before the modern nation-state and its attendant art movements? Brazil has always stood at the margins of historical debates about the concept 
of "Latin America," largely because of its notable differences from Spanish America in language, culture, and political institutions. ${ }^{5}$ One of the most significant distinctions between Portuguese America and both the Iberian homeland and colonial Spanish America was the absence of workshops and a guild system for the regulation of crafts. ${ }^{6}$ Nonetheless, colonial Brazil produced a vibrant material culture, which scholars must account for in writing our histories.

Our scholarly and theoretical apparatus is integral to these histories, an issue that has been discussed in relation to colonial Latin American visual culture and its postcolonial framework by Carolyn Dean, Dana Leibsohn, and Barbara E. Mundy. ${ }^{7}$ Michael Werner and Bénédicte Zimmermann's idea of histoire croisée (intercrossed history) offers a compelling model for thinking about and attending to a multiplicity of discourses and perspectives, including those of the scholars themselves, and to the processes by which these interact. ${ }^{8}$ Art historians wishing to explore such a framework thus must regard their methodologies as consubstantial with their objects of study, as well as attend to diachronic processes of transfer and transformation. I find this notion of "consubstantiality" of some consequence for art historians, bound as we are to the materiality of our objects.

\section{Tupinambá Featherwork}

Featherwork of the Tupinambá of early modern coastal Brazil, perhaps more than any other art form, has been emblematic of Brazil since European contact. ${ }^{9}$ As a geographic designation, the name "Brazil" was given to the territory in the sixteenth century as a descriptor for "the country where brazilwood grows," after which it was adapted into the generic referent for the coastal Tupi and other native inhabitants. ${ }^{10}$ Since the nineteenth century, scholars have regarded their feathered vestments as ethnological remnants of pre-contact Brazilian cultures. However, all extant Tupinambá featherwork was made in the sixteenth and seventeenth centuries within the ambit of Jesuit missions and colonial markets, and thus is a product of a colonial Brazilian interculture. As distinguished from the indigenous cultures of Mesoamerica and the Andes, the seminomadic Tupi had no large-scale, permanent architecture and no written language. ${ }^{11}$ The larger discipline's preference for urban cultures, architecture, painting, and sculpture has predisposed it, when directed toward the Americas, to the study of imperialistic artistic traditions and the neglect of less-monumental cultures. ${ }^{12}$ In the early modern period, however, Tupi feathered capes and crowns were among the most familiar New World artifacts; they were so crucial to the conceptualization of the Americas in early modern European scientific and religious contexts that the historian William Sturtevant referred to the development as the "Tupinambization" of the Atlantic world. ${ }^{13}$ These objects also remain crucial touchstones of Brazilian national and indigenous identity today.

Tupi featherworkers employed sophisticated techniques for mimicking the appearance of birds at particular stages of life, as in a down bonnet that captures the soft, fluffy appearance of a newborn bird (fig. 2). Fitted closely to the head like a skullcap and 


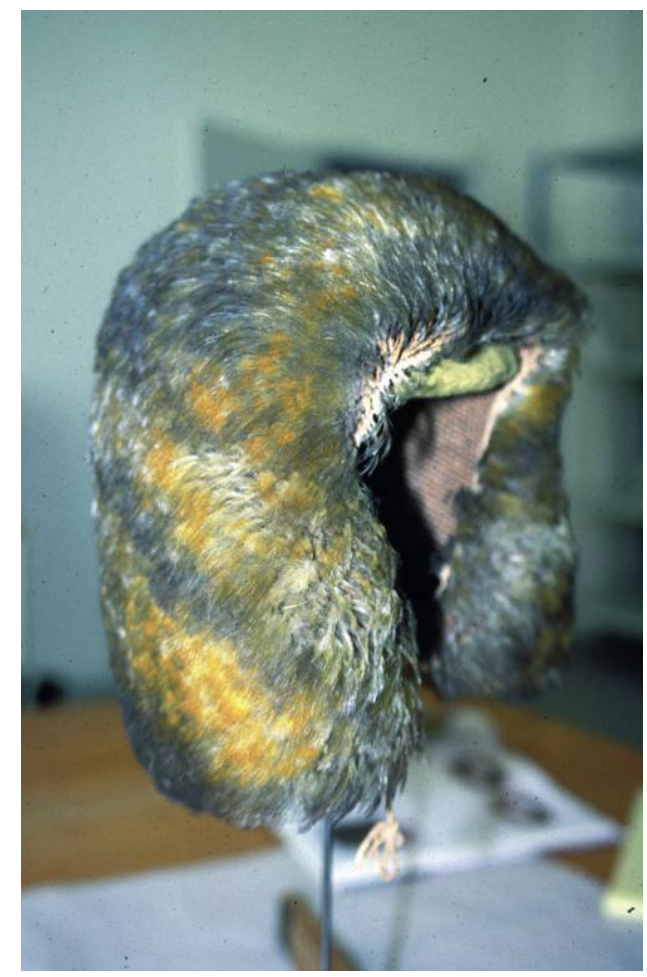

Fig. 2. Tupi feathered bonnet, 1500 or 1600 s, parrot-down feathers, height: $29 \mathrm{~cm}\left(11^{1 / 2} \mathrm{in}\right.$.).

Copenhagen, Nationalmuseet Etnografisk Samling (EH5932). Photo: Amy J. Buono

produced from parrot down, the bonnet's appearance has the look of a just-born fowl, as very young birds lack the firm contour feathers. In contrast, elaborately crafted full-body Tupi capes captured the sleek, structured profile of an adult scarlet ibis. In the creation of the bonnet, a distinct aesthetic choice was made in deciding to use down feathers over the more easily acquired exterior plumes, the result of which is an extraordinarily delicate textural effect that mimics the form of baby chicks. The binding technique shows how, in the case of the bonnet, the artist achieved this effect: pieces of down were bound to small sticks, which were attached perpendicularly to the webbed matrix below. ${ }^{14} \mathrm{Just}$ as the Tupi bonnet helped to transfigure its wearer into a spiritual aspect of a newborn bird, other featherwork vestments were in all likelihood similarly transformative. Feathers, in fact, were signs of divinity: they were rare, elite, prestigious materials accessed by those in power, material that in funerary contexts assisted the deceased in their journeys to other dimensions, and that acted as adornments in sacrificial rites and postbattle rituals. ${ }^{15}$

In the absence of Tupi written sources, how can scholars confirm these imitative dimensions of their featherwork? Some anthropologists use living Amazonian featherworking cultures as evidence of historical practices in the region. ${ }^{16}$ For example, Bororo infants in Matto Grosso are coated in a sticky substance and covered in toucan down with a textural effect comparable to that of the down bonnet. Though this garment is part of a rebirthing ritual that takes place in the contemporary world--thus distant in 
not only time but also cultural and geographic space from sixteenth-century Amerindian Brazil-it does echo ceremonial and material practices of featherwork discussed in sixteenth-century ethnohistorical documents. In my own work as an art historian, I combine disciplinary-based technical material analysis with historical epistemology, and a comparative anthropological approach when appropriate, in order to understand the functions of Tupi artistic practices and their cultural significance.

Tupi featherwork survives only in European museums as fragments of early modern collections that crossed the Atlantic through the agency of missionaries, merchants, and naturalists. ${ }^{17}$ Once in Europe, Tupi featherwork had an afterlife of ritual usage in courtly processions, funerals, and spectacles that helped endow the objects with sufficient value in the European context. To contend with these objects art historically therefore demands that they be contextualized within their diverse sites of social and cultural practice: both Brazil and Europe. They were produced in colonial Brazil, used in Jesuit-Tupi religious and secular contexts along the South American coasts, and then redeployed in pedagogical, ritual, and diplomatic contexts in early modern European universities and cities. Additionally, they serve today as signs of indigenous agency for the Tupinambá of Olivença in Bahia, who perceive these objects as links to their ancestral lineage that promote political legitimacy with the Brazilian government. Tupi featherwork thus sits at an intercrossed history, demanding a richer frame of analysis than can be deployed by seeing its objects as only historically bound traces of a lost, autochthonous heritage and as curious remains of the Kunst-und Wunderkammern.

\section{Mandingas}

From the ethnic Mandinga from the Guinea and Mina coasts came mandinga pouches (bolsas de mandingas in Portuguese), fabric or leather containers that originally held kabbalistic signs and numbers, as well as passages from the Qur'an. ${ }^{18}$ As James Sweet has discussed, in the early modern period, bolsas entered into circulation in both Islamic and Christian contexts - in West Africa, Brazil, and Southern Europe-filled with a remarkable range of efficacious natural and human-crafted artifacts from both sides of the Atlantic. ${ }^{19}$ Bolsas de mandingas often held diagrammatic drawings of Christian symbols like the Sacred Heart, as well as "orations," Christian texts written on folded pieces of paper (fig.3). One such oration was produced around 1700 in Brazil and brought to Lisbon by a former slave from Rio de Janeiro. This drawing would have originally been held in a small pouch. Very few of these bolsas survive today outside of the Inquisition records of colonial archives. A few pictorial vestiges have also been preserved, including a remarkable watercolor image of an Afro-Brazilian woman from the mid-eighteenth century by the Italian engineer Carlos Julião (1740-1811), who produced it while he was stationed in Rio de Janeiro and Minas Gerais (fig. 4). ${ }^{20}$

Bolsas de mandingas functioned like portable relics, bringing wealth, success, and power to their wearers. ${ }^{21}$ Seen as a form of sorcery, or feitiçaria, they were outlawed by the Portuguese Inquisition throughout the Portuguese Empire, even as they became a cultural 


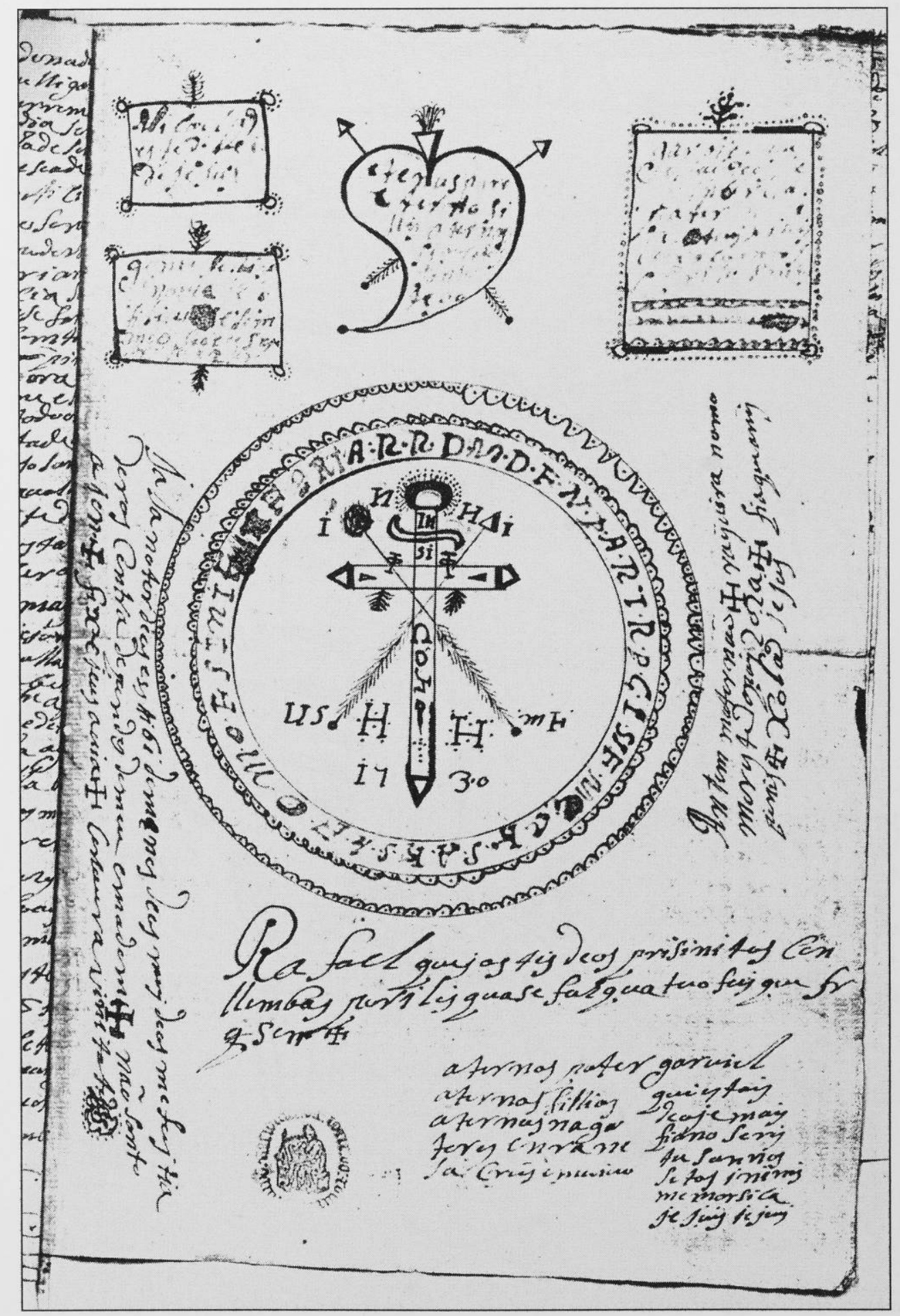

Fig. 3. Mandinga “oration,” before 1731, drawing. Lisbon, Portugal, Arquivo Nacional Torre do Tombo, Inquisition file of José Francisco Pedroso, native of Mina, Inquisição de Lisboa, Processo 1174 
commodity used by men and women of African descent, both free and enslaved, and also by white Portuguese men. They were worn by Africans and those of African descent on both sides of the Atlantic as a protection against enslavement and physical harm, while they were used by white Portuguese men for purposes of birth control and good fortune in gambling. ${ }^{22}$ Significantly, although an integral part of Brazil's material and cultural history, mandinga pouches transcend national, ethnic, and religious categories. These culturally intercrossed objects reveal that the "Brazilian-ness" of art and material history is at least as much a matter of where social practices occur as it is of where objects are invented or made. In turn, this has implications for our approach of Tupi featherwork; given that it was actively utilized in European rituals and political performances, the spaces of Brazil's colonial interculture must also be understood to encompass Europe itself.

While art historians have largely ignored the mandinga pouches, in which the more "artistic" elements are hidden from view inside the pouch itself, the functionally related but more ostentatious cast silver and gold pencas de balangandãs - beautifully wrought chains of amulets - have frequently appeared in art exhibitions. ${ }^{23}$ As we can see in the Marc Ferrez (1843-1923) photograph of an Afro-Brazilian woman adorned with jewelry (fig. 5), pencas, like bolsas de mandingas, were prominently displayed around the waist, and

Fig. 4. Carlos Julião (Luso-Italian, 1740-1811). Afro-Brazilian woman with mandinga pouch, ca. 177679, watercolor. From Riscos illuminados de Figurinhos de Brancos e Negros dos Usos do Rio de Janeiro e Serro Frio (Rio de Janeiro: Biblioteca Nacional e Ministério da Educação e Cultura, 1960): XX. Los Angeles, Getty Research Institute (91-B17429). Credit: Fundação Biblioteca Nacional, Rio de Janeiro, Brazil

Fig. 5. Marc Ferrez (Brazilian, 1843-1923). Portrait of an Afro-Brazilian woman with elaborate jewelry, and pencas de balangandãs around her waist, ca. 1885, photograph, dimensions unknown. Rio de Janeiro, Brazil, Acervo do Instituto Moreira Salles
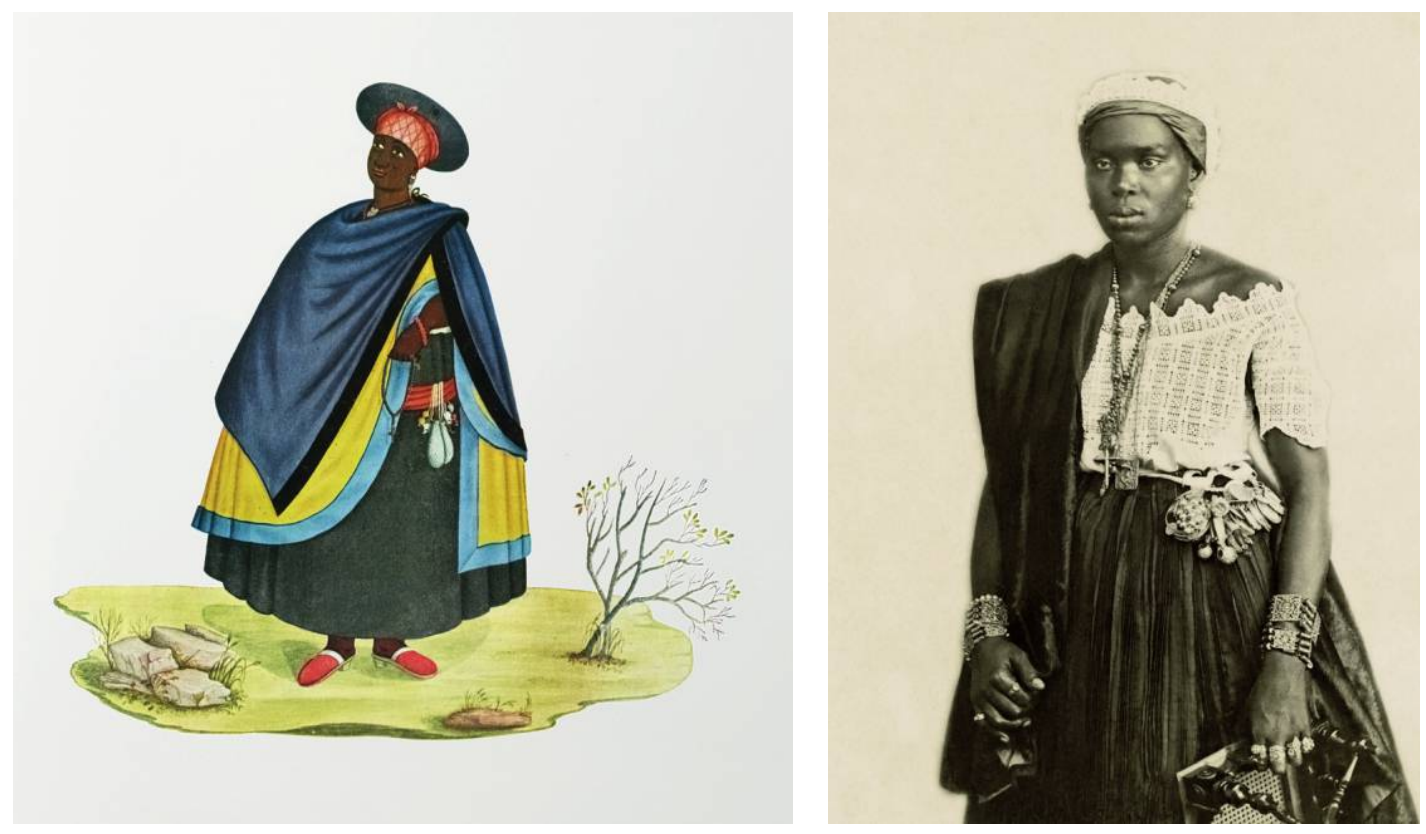
they served very similar apotropaic functions. Individual amulets took the shape of animals, fruits, Christian and African sacred figures, and whimsical tokens of everyday life. ${ }^{24}$ Crafted by the same religious workshops that produced silver monstrances and reliquaries that ornament Brazil's Baroque churches and twenty-first-century museums, many of these amulets-especially those in the form of body parts-functioned like miniaturized ex-votos. ${ }^{25}$ The difference in the discipline's treatment of the bolsas and the pencas can largely be attributed to the objects' materiality (the former are made of less-valuable fabric or leather whereas the latter are beautifully crafted precious metals) rather than any inherent difference in their sociocultural significance.

\section{Azulejos}

Decorative tiles - azulejos - were ubiquitous throughout early modern Brazil and Portugal. Simultaneously a type of earthenware, a form of mural, and a medium of painting, azulejos are the interior and exterior "skins" of buildings, forming a dominant visual element in the lived experience of urban existence in the region. However, despite their visual prominence, azulejos pose disciplinary challenges since tiles collapse some of the subdisciplinary precincts within art history, challenging the distinctions between "major" and "minor" art forms and epitomizing the concept of intercrossed history discussed in this essay.

The term azulejo is derived from the Arabic word $a z$-zulayi, meaning "polished stone." Spain's medieval Islamic inhabitants introduced decorative tiles for facing walls and paving floors, and in the fifteenth and sixteenth centuries, Portugal imported tiles from Spain for use in religious and private buildings. By the seventeenth century, blue and white tiles from the Netherlands, themselves a stylistic response to Ming dynasty porcelain, became a standard component in Iberian building practices. The Portuguese in turn exported azulejos in the seventeenth century to the Azores, Madeira, and Brazil. In Portugal and Brazil, no other art form played such a complex role in transforming urban spaces. All tilework was imported, as there was no craft industry in early modern Brazil, and therefore no azulejo workshops. This is the reverse of what happened with featherwork, which was produced in Tupi-Jesuit aldeias (missions) and exported to Europe. Commercially, Portugal profitably imported natural resources such as brazilwood and sugar from Brazil and then, also profitably, exported material like azulejos for remaking the urban fabric in its "own" image.

Tiles arrived in Brazil not as carefully handled trade goods but as ballast in ships. They were used to face buildings, providing a durable form of decoration in a hot and humid climate. One of the most significant examples is housed within the cloister of the Third Order of Saint Francis in Salvador de Bahia, which employed nearly 35,000 imported European azulejos to enliven its interior spaces. ${ }^{26}$ As Thijs Weststeijn details, the cloister's tilework dates from circa $1746-50$ and is based upon the Flemish artist Otto van Veen's Emblemata Horatiana, correlating thematically to the functional spaces lying behind and beyond the walls of the cloister (fig. 6). ${ }^{27}$ Unlike the frescoes and tiles of many 


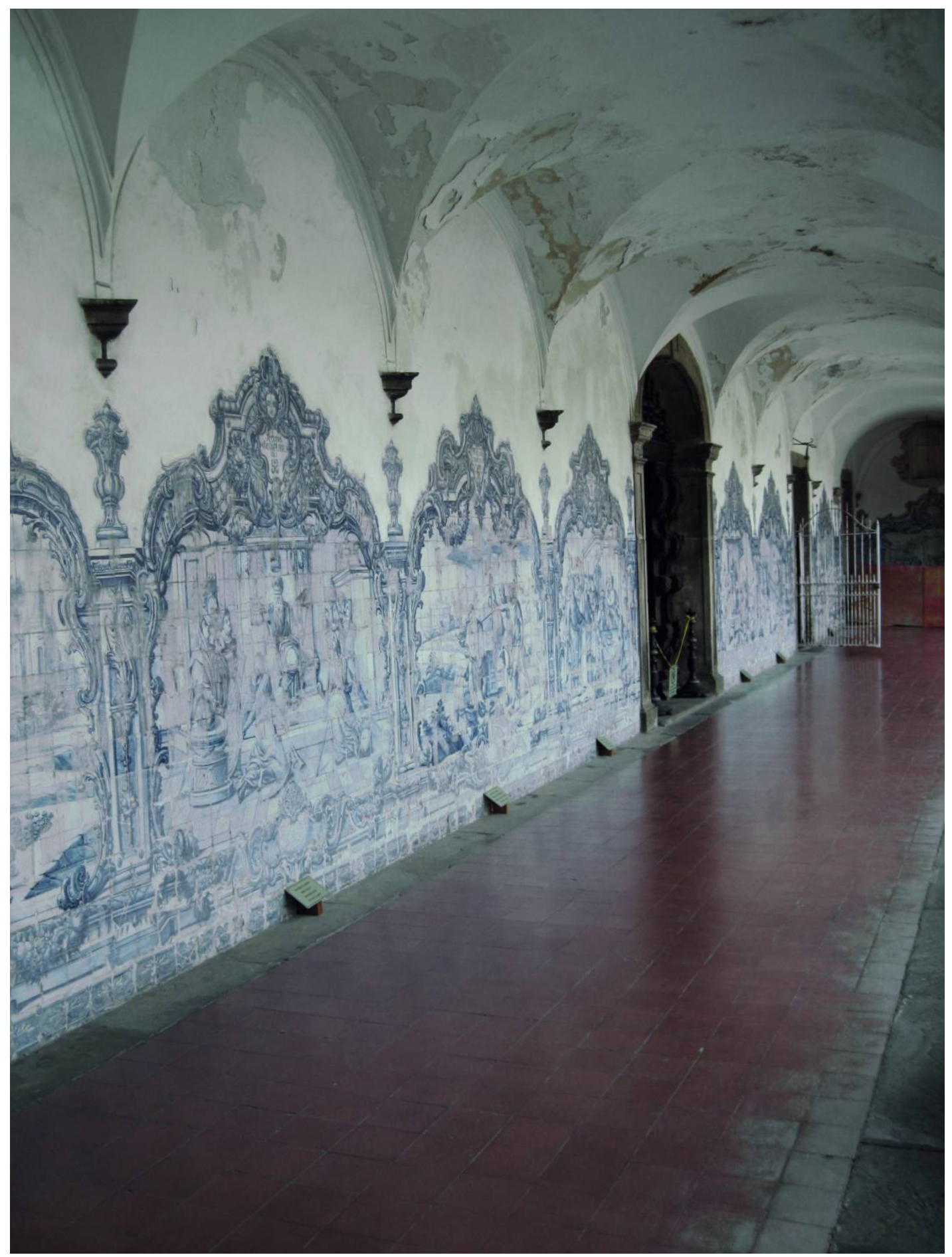

Fig. 6. Tilework cloister of the Convent of the Third Order of Saint Francis of Assisi, Salvador de Bahia, Brazil, 1708-52, imported European tiles. Photo: With kind permission Kirk L. Peterson, MD 
colonial cloisters throughout Latin America, the pictorial program of this Salvador cloister was allegorical rather than explicitly religious, drawing upon an emblematic literature that, like the blue and white style of the tiles themselves, was imported into the lusophone world from the Low Countries. On the ground floor alone, there are thirty-seven tile-paneled scenes featuring ancient gods, soldiers, and other emblematic iconography borrowed from van Veen. ${ }^{28}$ The azulejo cloister is thus not only transcultural but also transmedial, speaking to the way that images move across time, space, and artistic form.

The cloister's tilework exemplifies the complexities of visual and material culture found in intercrossed colonial contexts. The cloister's tiles may have been manufactured in either Portuguese or Dutch workshops, but it is clear they were not made in Brazil, since no ceramic or tile workshops had been established there. ${ }^{29}$ The style of the blue and white tile is itself a Dutch reworking in earthenware of a Chinese form of porcelain and deployed on a building material that traces its origins to medieval Islamic architecture. As for the subject matter, the meditative environment the azulejos created for the Franciscan friars pictorially derives from a Flemish artist's visualizations of an ancient Roman philosopher's writings. None of this obviated the centrality of azulejos to the artistic fabric of Brazil in the colonial period and beyond.

So ubiquitous has tilework become in the Brazilian environment, and in Brazilian modernity, that it has been appropriated by artists including Athos Bulcão (1918-2008) and Cândido Portinari (1903-62), as well as the landscape architect Roberto Burle Marx (1909-94), all of whom collaborated with Oscar Niemeyer (1907-2012) in designing elements of the modernist capital of Brasilia. ${ }^{30}$ One only need look toward the large-scale exhibitions of the Brazilian contemporary artist Adriana Varejão or to the installations at the Inhotim museum in Minas Gerais for evidence of the potency of this media form within Brazilian visual and institutional culture today. ${ }^{31}$

In this sense, azulejos have become as ubiquitous and even ostentatious a signifier of Brazil in the later colonial period and modern eras as Tupi featherwork had been in the early modern period. In very loose terms, both served as "skins," one transforming the Tupi or European body within a ritual context and the other transfiguring a building into a pictorial palimpsest. Because Tupi featherwork was fabricated by indigenous artisans within the territorial precincts of what is now the modern nation, for a wide variety of stakeholders it has appeared to possess an ontological claim to an innate "Brazilian-ness" that early modern azulejos lack. The fact that the surviving featherwork was produced within colonial missions, however, complicates the basis of this judgment. Unlike tiles and featherwork, bolsas de mandingas are outwardly drab, concealing within themselves elaborate diagrams and an assorted collection of apotropaic artifacts. The point of origin of azulejos, like that of mandinga bags, lies outside territorial Brazil, and they serve equally well as indices of the diverse nonindigenous ethnic, cultural, and religious strands that are woven into Brazil's colonial culture.

Featherwork, mandinga pouches, and azulejos are only a few of the colonial Brazilian art forms in which multiple cultures, temporalities, and epistemologies are 
intercrossed. None of these fits comfortably within traditional historical periods, stylistic/formal categories, or nationally determined art historical narratives. They do, however, reveal much about the complexities of how Brazil's rich cultural and material heritage was formed - a picture that is not as readily visible when restricting our studies to disciplinarily normative objects. These art forms offer a similarly rich portrait of the entanglement of Brazil's heterogenous visual and material cultures, an understanding of which can contribute much to our knowledge of the colonial period, and of the role of materiality in shaping cultural, political, and social lives.

\section{Parable}

Constructing a history of colonial Brazilian art and material culture is, in both the usual and the Foucauldian senses of the word, a disciplinary undertaking. Rio de Janeiro's Civil Police Museum may serve as a parable for understanding how the material culture of Brazil intersects with institutional power and disciplinary practice. Founded in 1912 , in the former police headquarters, the museum first functioned as an instructional facility for police academy students, and at some point, likely in the 1930s, it opened to the public at large (fig. 7). ${ }^{32}$ This museum served several functions from the outset: it celebrated the history of the police as an institution and it was used to instruct future police officers about procedures and crime in the city. The museum also sought to teach and display aspects of crime to Rio's citizenry by featuring criminal objects (weapons, poisons, gambling materials, drug paraphernalia, astrology charts), criminal behavior

Fig. 7. Police School classroom in the Civil Police Museum, Rio de Janeiro, ca. 1912. Photograph from Boletim Policial, 2 February 1912. Courtesy of Civil Police Museum, Rio de Janeiro. Photo: With kind permission of Wilson da Costa

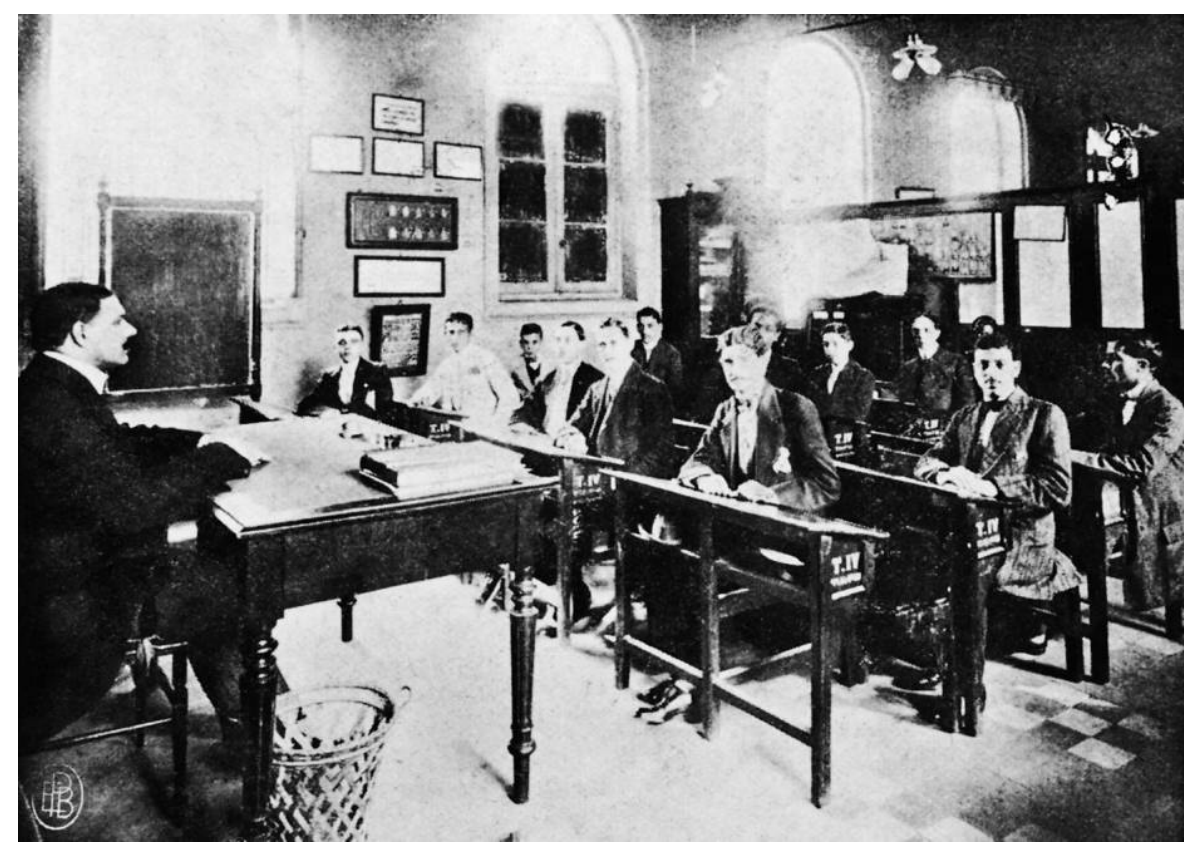


(detective novels, re-creations of crime scenes), and technologies of crime (fingerprinting machines, cameras, phrenological materials), as well as charting histories of the relationships between the police academy and the government (through objects such as uniforms, insignias, paraphernalia, and money). One particularly interesting selection of objects is found in the legal medical collection of the museum, where rooms contain wax sculptures of wounds, lacerations, and other visible traumas to the body that a police officer might encounter on a crime scene (fig. 8).

By the 1920 , the museum also served as a place of incarceration for spiritually dynamic objects of Afro-Brazilian religions such as Candomblé and Umbanda. ${ }^{33}$ These were confiscated from Candomblé terreiros, or temples, which police suspected of harboring communist sympathizers, and other "disruptive" elements. ${ }^{34}$ As noted by sociologist Alexandre Fernandes Corrêa, the police were instructed to place anything "sinister, strange, primitive, [or] grotesque," or that had "immaterial and intangible ritual dimensions," into a special space in the museum called the Coleção Museu de Magia Negra (Museum Collection of Black Magic). ${ }^{35}$ Officers who were assigned to this post became reluctant ethnographers and historians through the research they conducted about the artifacts and how they were used. They also disciplined these objects in two ways: by attempting to contain and restrict their power, and by subjecting them to ethnographic and cultural study, inadvertently, as it were, turning them into objects of scholarly

Fig. 8. Gallery of the legal medicine room of the Civil Police Museum, Rio de Janeiro, present-day installation of wax models. Courtesy of Civil Police Museum, Rio de Janeiro. Photo: With kind permission of Wilson da Costa

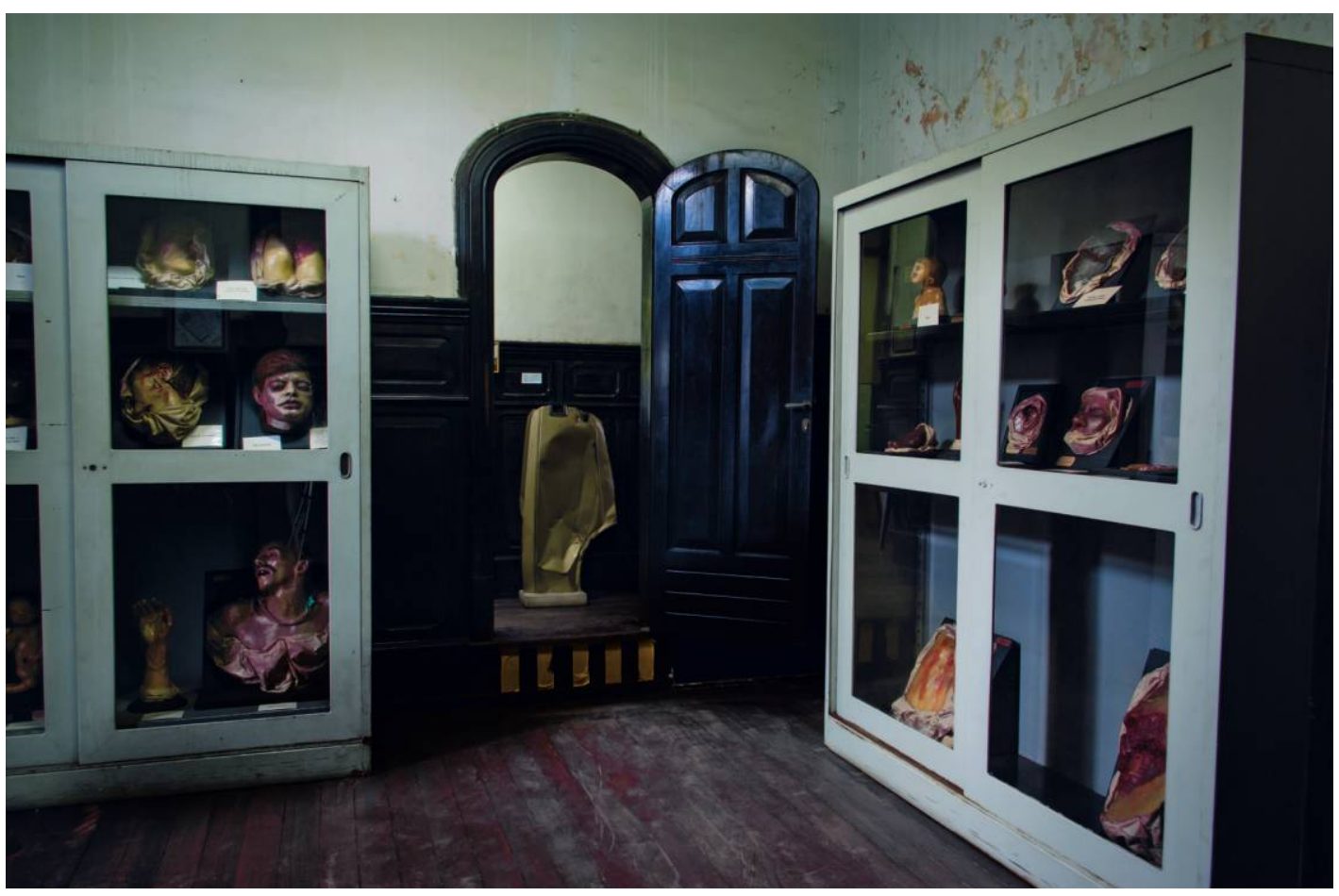


scrutiny. Paradoxically, though, the very act of incarcerating these objects had the effect of officially confirming and at some level perpetuating the real presence of their magical powers. In Werner and Zimmermann's terms, the museum is the embodiment of "intercrossed histories."

In 1938, under the aegis of Mario de Andrade, the Collection of Black Magic was declared Brazil's first ethnographic collection registered as national patrimony. ${ }^{36}$ This action was symptomatic of the Vargas regime, which alternately suppressed and promoted Afro-Brazilian religious practices depending on the political exigencies of the moment. ${ }^{37}$ This the collection of Afro-Brazilian objects was inserted into the museum's canonical, documentary history of the civil police, existing alongside portraits of past officials, collections of antiquated truncheons and handcuffs, and period rooms, such as that of the old police commissioner. This is precisely what makes the museum such a fascinating and unsettling experience; its political and cultural multidimensionality can be richly mined by art historians, museologists, anthropologists, and political historians alike.

Art historians and other scholars of colonial Brazil-at times reluctantly, like Rio's civil police officers assigned to the museum—convert feathered capes, mandinga pouches, pictorial tilework, and many other objects into scholarly artifacts. This act has real-world effects, just as seizing and studying Candomblé materials did; it perhaps encourages their preservation, affects their market values, or shifts the balance from thinking of them as living, potent entities or as part of the mundane realities of urban life, or even as essential elements of national heritage. This process is a continuation of the already rich, intercrossed lives of these objects. Attending to their prior histories, and to the nature of our own contributions, will help ensure that the full complexity of Brazil's past and present is more fully understood.

Amy Buono is a visiting professor and researcher at the Instituto de Artes at the Universidade do Estaduo do Rio de Janeiro, specializing in the art and material culture of colonial Brazil.

Notes This paper began in two conference settings: a panel at LASA 2012 in San Francisco and a Getty-sponsored 2012 workshop for the Project New Art Histories UNIFESP in São Paulo. I am grateful for the valuable feedback provided by many colleagues along the way: Maite Alvarez, Jens Baumgarten, Charlene Villaseñor Black, Roberto Conduru, Tatiana Flores, Pablo Gómez, Charles Hatfield, Harper Montgomery, Lisa Pon, and Elena Shtromberg. I would especially like to thank Jeanette Favrot Peterson, Aleca Le Blanc, and the anonymous reviewers of the Getty Research Journal for their incisive comments. Finally, I offer my special thanks to Cyro Advincula, the director of the Civil Police Museum in Rio de Janeiro, and the generosity of photographer and Police Inspector Wilson da Costa Vieira Jr.

1. Myriam Andrade Ribeiro de Oliveira, O Aleijadinho e sua oficina (São Paulo: Editora Capivara, 2002).

2. Alfredo Bosi, Colony, Cult and Culture, ed. Pedro Meira Monteiro, trans. Robert P. Newcomb (Dartmouth: University of Massachusetts Dartmouth, 2008); and Sunil Bald, “In Aleijadinho's Shadow: Writing National Origins in Brazilian Architecture,” Thresholds 23 (2002): 74-81.

3. Dipesh Chakrabarty, Provincializing Europe: Postcolonial Thought and Historical Difference 
(Princeton, N.J.: Princeton University Press, 2000), 113. These issues are also discussed by Johannes Fabian, Time and the Other: How Anthropology Makes Its Object (New York: Columbia University Press, 1983); Néstor García Canclini, Hybrid Cultures: Strategies for Entering and Leaving Modernity, 2nd ed. (Minneapolis: University of Minnesota Press, 2005); and Bosi, Colony, Cult and Culture.

4. In fact, much the same can be said about many kinds of art objects, including (but certainly not limited to) Old Master European religious art, which for many viewers retains its religious potency. With very rare exceptions, however, art historians tend to overlook this sort of achronicity when discussing canonical art objects.

5. Leslie Bethell, "Brazil and 'Latin America," Journal of Latin American Studies 42, no. 3 (August 2010): 457,461 .

6. Bailey W. Diffie, A History of Colonial Brazil, 1500-1792, ed. Edwin J. Perkins (Malabar, Fla.: Robert E. Krieger Publishing, 1987), 85.

7. Carolyn Dean and Dana Leibsohn, "Hybridity and Its Discontents: Considering Visual Culture in Colonial Spanish America," Colonial Latin American Review 12, no. 1 (June 2003): 5-35; and Barbara E. Mundy and Dana Leibsohn, "History from Things: Indigenous Objects and Colonial Latin America," World History Connected 9, no. 2 (June 2012).

8. Michael Werner and Bénédicte Zimmermann, "Beyond Comparison: Histoire croisée and the Challenge of Reflexivity," Religion and History 45 (2006):30-50. I have opted to translate histoire croisée as "intercrossed history" for the purposes of this article, but for the difficulties of translating the term, see Jani Marjanen, “Undermining Methodological Nationalism: Histoire croisée of Concepts as Transnational History," in Mathias Albert et al., eds., Transnational Political Spaces: Agents, Structures, Encounters (Frankfurt: Campus Verlag $\mathrm{GmbH}$ ), 244.

9. Amy J. Buono, “'Their Treasures Are the Feathers of Birds': Tupinambá Featherwork and the Image of America," in Alessandra Russo, Gerhard Wolf, and Diane Fane, eds., Images Take Flight: Feather Art in Mexico and Europe (1400-1700) (Chicago: Hirmer/University of Chicago Press, forthcoming 2015).

10. "Brazil" was originally a Celtic word for the mineral called "breazail " (meaning red). See the first chapter of Eduardo Bueno and Ana Roquero, Pau-Brasil (São Paulo: Axis Mundi, 2002), 29.

11. John M. Monteiro, "The Crisis and Transformations of Invaded Societies: Coastal Brazil in the Sixteenth Century," in Frank Salomon and Stuart B. Schwartz, eds., Cambridge History of Native Peoples of the Americas (Cambridge: Cambridge University Press, 1999), 973-1024.

12. Joanne Rappaport and Tom Cummins, Beyond the Lettered City: Indigenous Literacies in the Andes (Durham, N.C.: Duke University Press, 2012).

13. The term Tupinambization was first applied in William C. Sturtevant's essay "Le Tupinambisation des Indiens d'Amérique du Nord," in Gilles Thérien, ed., Les figures de l'indien (Montreal: Université du Québec à Montréal, 1988), 293-303. See also William C. Sturtevant, "First Visual Images of Native America," in Fredi Chiappelli, Michael J. B. Allen, and Robert Benson, eds., First Images of America: The Impact of the New World on the Old (Berkeley: University of California Press, 1976), 417-54.

14. Karen Stemann Peterson and Anne Sommer-Larsen, “Techniques Applied to Some Feather Garments from the Tupinamba Indians, Brazil," FOLK 21-22 (1979/80):263-70.

15. Alfred Métraux, La civilisation matérielle des tribus tupí-guaraní [The material culture of the Tupi-Guarani tribes], (Paris: Librairie Orientaliste Paul Geuthner, 1928).

16. Berta G. Ribeiro, "Bases para uma classificação dos adornos plumários dos índios do brasil," Arquivos do Museu Nacional (Rio de Janeiro) 43 (1957): 59-72; and Eduardo Viveiros de Castro, From the Enemy's Point of View: Humanity and Divinity in an Amazonian Society (Chicago: University of Chicago Press, 1992).

17. Elke Bujok, Neue Welten in Europaischen Sammlungen: Africana und Americana in Kunstkam- 
mern bis 1670 (Stuttgart: Dietrich Reimer Verlag GmbH, 2004); Amy J. Buono, Feathered Identities and Plumed Performances: Tupinambá Interculture in Early Modern Brazil and Europe (PhD diss., University of California, Santa Barbara, 2007).

18. Sylvanie A. Diouf, “African Muslims in Bondage: Realities, Memories, and Legacies," in Joanne Braxton and Maria I. Dietrich, eds., Monuments of the Black Atlantic: Slavery and Memory (Münster: LIT Verlag, 2004), 77-89.

19. James H. Sweet, "Slaves, Convicts, and Exiles: African Travelers in the Portuguese Atlantic World, 1720-1750," in Caroline Williams, ed., Bridging the Early Modern Atlantic World: People, Products, and Practices on the Move (Farnham, U.K.: Ashgate, 2009), 196-97.

20. This case is detailed and illustrated in Daniela Buono Calainho, Metrópole das Mandingas: Religiosidade negra e Inquisição portuguesa no Antigo Regime (Rio de Janeiro: Garamond, 2008).

21. Laura de Mello Souza, The Devil and the Land of the Holy Cross: Witchcraft, Slavery, and Popular Religion in Colonial Brazil, trans. Diane Grosklaus Whitty (Austin: University of Texas Press, 2003); Diouf, "African Muslims in Bondage”; Sweet, "Slaves, Convicts, and Exiles”; and Calainho, Metrópole das Mandingas.

22. Sweet, "Slaves, Convicts, and Exiles," 198-99.

23. See especially Edward J. Sullivan, ed., Brazil: Body and Soul (New York: Guggenheim Museum, 2001).

24. Laura Cunha and Thomas Milz, Joias de Crioula [Jewelry of the Brazilian Crioula] (São Paulo: Editora Terceiro Nome, 2011); and Raul Lody, Dicionário de Arte Sacra and Técnicas Afro-Brasileiras (Rio de Janeiro: Impresso no Brasil, 2003).

25. Cunha and Milz, Joias de Crioula.

26. J. M. Santos Simões, Azulejaria portuguesa no Brasil (1580-1822) (Lisbon: Fundação Calouste Gulbenkian, 1965), is one of the foundational works. For more recent examinations, see Thijs Weststeijn, “Otto Vaenius' Emblemata Horatiana and the Azulejos in the Monastery of Sao Francisco in Salvador De Bahia," De zeventiende eeuw 21 (2005): 128-45; Maria Alexandra Trinidade Gago da Câmara, "Portuguese Baroque Art in Colonial Brazil: The Heritage of 18th-Century Azulejos," in Csaba Lévai, ed., Europe and the World in European Historiography (Pisa: Edizioni Plus/Pisa University Press, 2006), 267-80; and Sílvia Barbosa Guimarães Borges, “Questões em torno de autorias na arte azulejar: O caso da Igreja do Convento Franciscano de Salvador,” Anais do XXVI Simpósio Nacional de História, ANPUH, São Paulo, July 2011, 1-9.

27. Weststeijn, “Otto Vaenius' Emblemata Horatiana,” 129-30.

28. Weststeijn, “Otto Vaenius' Emblemata Horatiana,” 128-29.

29. For a recent discussion of archival sources and possible workshops, see Borges, "Questões em torno de autorias."

30. Carlos Marcelo, Os criadores: Athos Bulcão, Burle Marx, Lúcio Costa, Oscar Niemeyer (Brasilia: Multicultural Arte e Comunicação, 2010); and Jean-François Lejeune, ed., Cruelty and Utopia: Cities and Landscapes in Latin America (New York: Princeton Architectural Press, 2005).

31. Louise Neri, “Brave New Worlds: Adriana Varejão’s Baroque Territories,” in Louise Neri and Paulo Herkenhoff, eds., Adriana Varejão (São Paulo: O Autor, 2001), 13-15.

32. Alexandre Fernandes Corrêa, O Museu Mefistofélico e a distabuzação da magia: Análise do tombamento do primeiro patrimônio etnográfico do Brasil (São Luis, Brazil: EDUFMA, 2009).

33. On the materiality and historicity of candomblé objects in Salvador de Bahia collections, see Roger Sansi-Roca, “The Hidden Life of Stones: Historicity, Materiality, and the Value of Candomblé Objects in Bahia," Journal of Material Culture 10, no. 2 (2005), 139-56.

34. Yvonne Maggie, Medo do feitiço: Relações entre magia e poder no Brasil (Rio de Janeiro: Arquivo Nacional, 1991); and Paul Christopher Johnson, Secrets, Gossip, and Gods: The Transformation of Brazilian Candomblé (New York: Oxford University Press, 2002). 
35. Corrêa, O Museu Mefistofélico, 409.

36. This collection was registered with Brazil's then-newly formed SPHAN (Serviço do Patrimônio Histórico e Artístico Nacional, 1937-46), the governmental organ for cultural patrimony. Corrêa, O Museu Mefistofélico, 406.

37. Both Johnson, Secrets, Gossip, and Gods, and Daryle Williams, Culture Wars in Brazil: The First Vargas Regime, 1930-45 (Durham, N.C.: Duke University Press, 2001), provide discussions of the Vargas years in relation to museums. 